\title{
Study on the Properties of Waste Apatite Phosphogypsum as a Raw Material of Prospective Applications
}

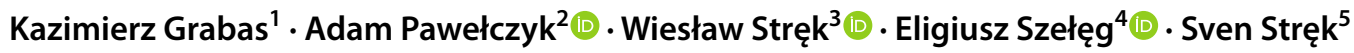

Received: 2 November 2017 / Accepted: 2 May 2018 / Published online: 11 May 2018

(c) The Author(s) 2018

\begin{abstract}
This paper presents the results of the study on chemical and the physical properties of waste phosphogypsum (PG) of apatite origin from the former chemical plant Wizow, Poland which are important for further processing and economic use. The research was carried out to verify whether the waste might be useful as a raw material for rare earth elements (REE) recovery and the manufacture of building materials. The following methods were chosen: X-ray diffraction, scanning electron microscopy with an energy-dispersive X-ray detector, atomic absorption spectrometry, inductively coupled plasma spectrometry, differential thermal analysis, thermogravimetry, and gamma spectrometry with natural radioactive contamination analyzer. It has been proven that the chemical physical properties of phosphogypsum provide an opportunity to utilize this waste material as a source of REE and raw material for building purposes. PG contains an overall amount of REE in the interval of $0.343-0.637 \%$ by mass and does not show radioactivity level which would exclude it from construction purposes. The presented results serve as the basis for currently available technological directions in the management of apatite PG for useful trade products, which creates a chance for the elimination of its storage necessity by further processing.
\end{abstract}

\section{Graphical Abstract}

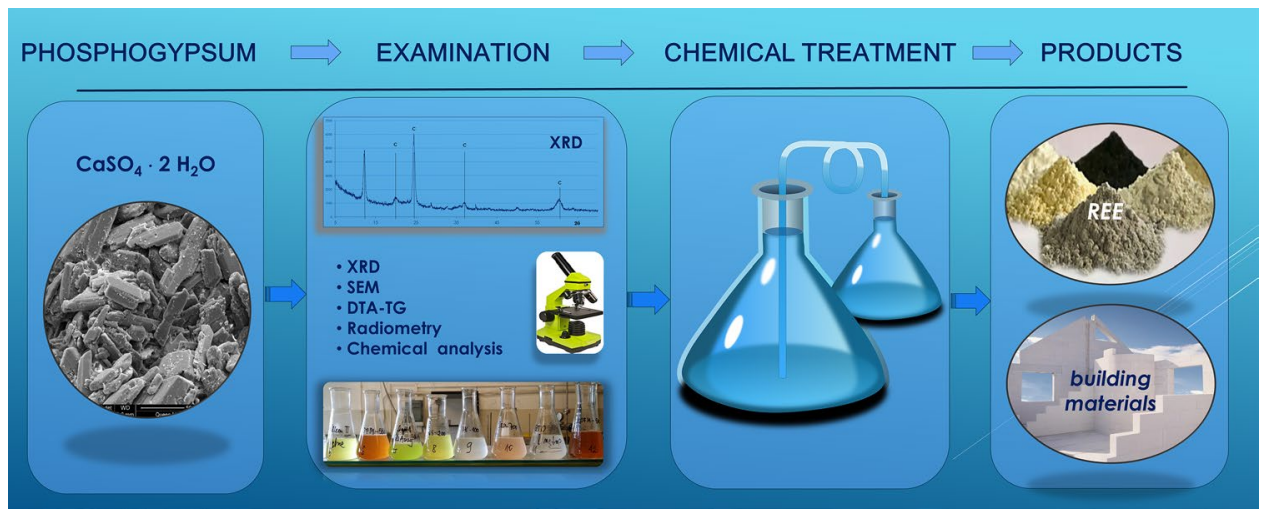

Keywords Phosphogypsum $\cdot$ Waste $\cdot$ Phosphogypsum contamination $\cdot$ Rare earth elements $\cdot$ Morphological characterization

Adam Pawełczyk

adam.pawelczyk@pwr.edu.pl

Extended author information available on the last page of the article

\section{Introduction}

Nowadays, rare earth elements (REEs) have a great impact on the development of new technologies, e.g., strategic economy sectors [1-3] are considered to be the flywheel of modern economics and serve as the basis for technological developments. Economy politics of developed countries is 
aiming towards a decrease in the dependence on raw materials supplied by countries that hold a monopoly for the worldwide supplies. Raw material accessibility and the security of supply influence the economics; furthermore, the increasing demand and limited raw material resources enforce the search for new REE deposits [2-5].

Europe does not have its own primary sources of REE, but is in fact, one of the most significant consumers of REE. REEs are treated as critical raw materials and have been put on a list of raw materials that are crucial for the European Union (EU) economy [3, 6, 7]. The Raw Materials Initiative was put forward in 2008 to tackle the challenges related to the access to raw materials, REE among others. The new Communication from the Commission to the European Parliament on the 2017 list of Critical Raw Materials for the EU updates the 2014 list of critical raw materials. The list is used by the Commission as a supporting element when negotiating trade agreements, challenging trade-distortive measures, developing research and innovation actions, and implementing the 2030 Agenda on Sustainable Development and its Sustainable Development Goals (COM(2017) 490).

A search for new REE extraction methods has considerable significance; until recently, they were considered technically, technologically, or economically unattractive [1-5, 8]. Therefore, new sources of crucial raw materials are gaining importance, e.g., recycling and processing of electronic waste, mining waters, sediments, mine burrows, black coal, and fly ashes [8-17].

One source of REEs that should be taken into consideration is apatite phosphogypsum. It is generated as a side product which is neutralized by storage during the production of phosphoric acid from phosphate raw materials by the so-called wet methods. They consist in the decomposition of phosphate raw materials by sulfuric acid [18-20] and may be carried out according to

- hemihydrate $(\mathrm{HH}, \mathrm{x}=1 / 2)$,

- dihydrate $(\mathrm{DH}, \mathrm{x}=2)$,

- and anhydrite $(\mathrm{AH}, \mathrm{x}=0)$ processes.

The main reaction is as follows:

$$
\begin{aligned}
\mathrm{Ca}_{10}\left(\mathrm{PO}_{4}\right)_{6} \mathrm{~F}_{2} & +10 \mathrm{H}_{2} \mathrm{SO}_{4}+\mathrm{xH}_{2} \mathrm{O} \rightarrow 6 \mathrm{H}_{3} \mathrm{PO}_{4}+2 \mathrm{HF} \\
& +10 \mathrm{CaSO}_{4} \cdot \mathrm{xH}_{2} \mathrm{O} .
\end{aligned}
$$

In the dihydrate method (DH-process), REEs account for about $20 \%$ or more, passing to the phosphoric acid solution; the rest of the REE remains in the waste of phosphodihydrate (PHD). In the hemihydrate method (HH-process), REE almost entirely pass to the semi-hydrate phosphogypsum (PSH) [21-24].

The worldwide production of phosphate raw materials in 2014 amounted to $225 \mathrm{Mt}$ (million tons) and predictions for 2018 are thought to amount to $258 \mathrm{Mt}$ [25]. In Europe (including Russia), there are over 30 phosphoric acid production plants, in which some still produce or used to produce the acid from apatite. It should be mentioned that when phosphorite is used instead of apatite, the obtained waste of phosphogypsum is more contaminated and contains far less recoverable REE than that from apatite. Thus, only the latter should be considered as a potential source of REE and, at the same time, as a raw material for the manufacture of building materials used in civil engineering.

One of the most important PG parameters, particularly determining its application in civil engineering, is its radioactivity induced by the radioactive elements that it contains [26]. In Poland, ensuring proper hygienic and health conditions regarding building materials and ipso facto safety is regulated by two law acts: Building Law and Atomic Law, as well as executive regulations [27] and EU recommendations [28]. According to the regulations mentioned above, it is forbidden to use materials in which the limit of natural radioactive elements is exceeded for building materials.

The former chemical plant Wizow, before termination of the phosphoric acid manufacturing, used Kola apatite concentrate as a raw material. It is produced by calcination of igneous phosphate ores occurring on Kola Peninsula in the Russian Federation and contains 1-2\% of REE [8, 18, 24, 29]. This raw material was widely used in Central and Eastern European countries, including Poland, mainly for phosphoric acid production intended for fertilizer production purposes as well as the production of household chemicals [29-33]. It is estimated that the PG pile in Wizow contains about $5 \mathrm{M}$ tons of the waste $[22,23]$ with a mean REE content of $0.3-0.7 \%$.

REE content in phosphate raw materials is significantly lower than in real REE ores. Deposits of rare earth metals which are currently extracted contain 3-15\% of rare earth oxides (REO). However, due to the fact that great quantities of phosphoric acid are processed into phosphoric acid, the rare earth metals accumulate in the waste PG which may be a valuable source of REE $[8,11]$. It is possible to extract REE from PG inter alia by mineral acid extraction [17, 22, 29, 30, 34, 35].

Former chemical plant Wizow is located in the southwest part of Poland approximately $4 \mathrm{~km}$ north of the city of Boleslawiec, about $45 \mathrm{~km}$ from the German and $60 \mathrm{~km}$ from the Czech border (Fig. 1). Until 1983, the chemical plant produced phosphoric acid by the dihydrate method (DH-process); however, from 1984, the production technology was changed to the hemihydrate method (HH-process), which had been used until 2006. The main waste product was the phosphogypsum which includes mainly calcium sulfate hemihydrate contained with traces of phosphoric acid, fluorine compounds, and approximately $0.6 \%$ of REO [23]. 


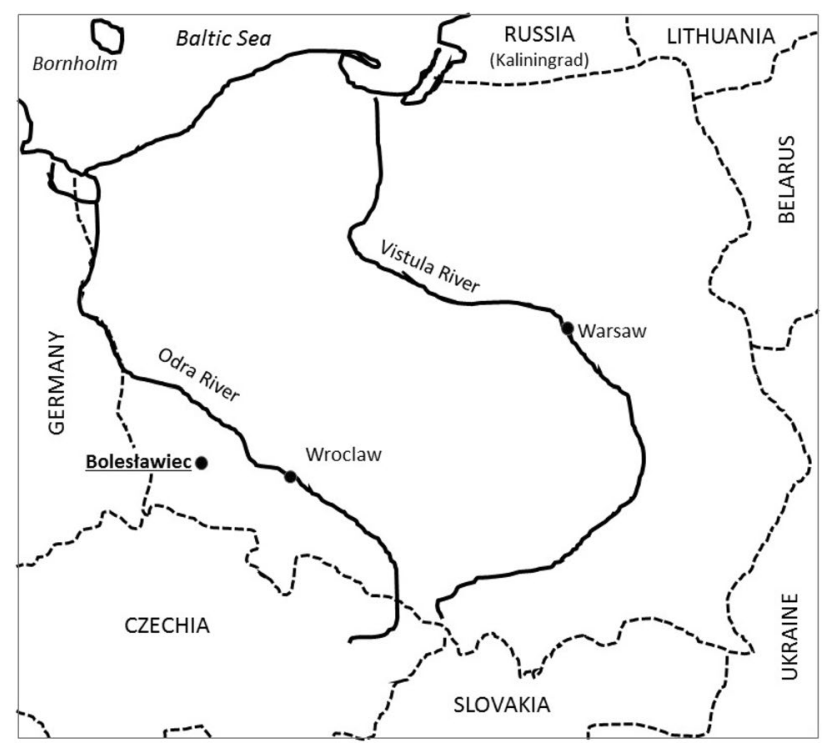

Fig. 1 Location of the former chemical plant Wizow

Being an industrial waste from the production of phosphorus acid, the apatite phosphogypsum heap amounts to about 5 million tons [17, 21-23]. The heap is approximately $1000 \mathrm{~m}$ long and $200 \mathrm{~m}$ wide and more than $30 \mathrm{~m}$ high, covering about 20 ha. Geodetic measurements estimate the volume of the heap at $3.3 \times 10^{6} \mathrm{~m}^{3}$. The district court declared bankruptcy of Wizow chemical plant in 2006. Lack of investors has led to a demolition of most of the production buildings and warehouses in 2014.

The facilities of the Wizow chemical plant, especially the phosphogypsum heap, as well as the nearby retention ponds that collectively amount to $7256 \mathrm{~m}^{3}$, have had a negative impact on the environment. The surrounding drainage trench discharges the waste waters from the drainage system under the heap along with the surface run-off into one of the reservoirs. The waste waters are contaminated mainly with fluorides, sulfide, and phosphates. The contaminated waters find their way to the groundwater and consequently to the Bóbr river that is only about $500 \mathrm{~m}$ away. The area of the chemical plant has been fitted with a network of 40 piezometric wells in order to monitor groundwater that includes eight wells for a direct monitoring of the storage area. The remaining wells were used to monitor the retention ponds along with the plant's quality of its surface water. Tests of waters from the eight piezometric wells conducted in 2015 indicate significant exceedance of acceptable norm levels for the class five groundwater. The contained soluble compounds in PG, especially the free acids, sulfates and fluorides, are supremely dangerous for the soil and the groundwater.

However, the research conducted by the State Environment Inspectorate in Wroclaw has not shown any exceedance of the acceptable norms of heavy metals such as $\mathrm{Zn}, \mathrm{Pb}, \mathrm{Cu}$, $\mathrm{Cd}, \mathrm{Hg}$, and As.

\section{Materials and Methods}

Two random samples of PG waste from Wizow plant were collected for testing. Samples in the amount of $5 \mathrm{~kg}$ were taken from the upper layer $(0-30 \mathrm{~cm})$ - PG1, and also from $1 \mathrm{~m}$ below the upper layer of heap-PG2. Collected samples were then pulverized, homogenized, and dried at $55^{\circ} \mathrm{C}$.

Samples collected in March 2013 were taken from the depth of 0-30 cm and below $1 \mathrm{~m}$. Content of phosphogypsum in deeper levels of the heap remains close to the upper layers due to low filtration-something that was determined during the filtration tests (see "Scanning Electron Microscopy (SEM)" section). Grain size, size distribution of crystals, as well as the permeability coefficient were determined in the samples. Moreover, X-ray diffraction (XRD), scanning electron microscopy (SEM), differential thermal analysis (DTA) and thermogravimetry (TG), and analyses of chemical contents were conducted using the atomic absorption spectrometry (AAS) and inductively coupled plasma (ICP) methods.

In November 2011, a series of 12 drillings were conducted throughout the entire length of the heap for analytical purposes. The depth of the drillings varied between 29 and $42 \mathrm{~m}$. Combined length of the drillings amounted to 410 LM. $2 \mathrm{~kg}$ sample was obtained from each $1 \mathrm{LM}$ of the drillings. The samples were then averaged and 12 aggregate samples were subjected to tests in the Activation Laboratories Ltd. in Ancaster, Ontario to determine a content of 39 components. This was done by melting the analytical sample with $\mathrm{Na}_{2} \mathrm{O}_{2}$ and direct analysis using the mass spectrometry method (MS). Four samples from the depths of 1, 15, 30, and $42 \mathrm{~m}$ were subjected to tests of bulk density and permeability coefficient by a soil testing in a specialist laboratory of Wroclaw University of Science and Technology.

\section{Grain Size and Crystal Size Distribution}

Once dried in $105^{\circ} \mathrm{C}$, the samples were tested using Mastersizer 2000 laser diffractometer, equipped with Hydro $2000 \mathrm{~S}$ dispersion unit (Malvern) with size range capacity 0.100 to $1000.000 \mu \mathrm{m}$.

\section{X-Ray Diffraction (XRD)}

To determine the phase composition of PG [different fraction shares of calcium sulfate (VI)] and mineral impurities, an X-ray diffractometer was used: the MPD X'Pert PRO Pw3040/60 of PANanalytical, geometry Bragg-Brentano, Theta-Theta. Measurement conditions were as follows: 
range $2.6^{\circ}-65^{\circ} 2$ Theta; counting time $-300 \mathrm{~s}$; scan rate0.012 Theta; $\mathrm{CuK} \alpha$ radiation, Ni filter to remove K-beta radiation, acceleration voltage of $40 \mathrm{kV}$, and current of $40 \mathrm{~mA}$. Data analysis and percentage shares of mineral phases were conducted on the basis of Rietveld method using the HighScore+ software supplied with the current ICSD and PDF4+ databases.

\section{Scanning Electron Microscope}

Examinations of PG structure were carried out at the Laboratory of Queen Mary University in London and Faculty of Earth Sciences of University of Silesia in Katowice. Queen Mary Laboratory used a scanning electron microscope, type FEI Inspect F, equipped with an energy-dispersive X-ray spectroscope (EDS) (Inca Energy System, Oxford Instruments, High Wycombe, UK). Semi-quantitative analysis was performed using the following standards: $\mathrm{O}-\mathrm{SiO}_{2}$, $\mathrm{F}-\mathrm{MgF}_{2}, \mathrm{Si}-\mathrm{SiO}_{2}, \mathrm{Fe}-\mathrm{FeS}_{2}, \mathrm{Ca}-$ wollastonite, $\mathrm{Sr}-$ $\mathrm{SrF}_{2}$, and $\mathrm{La}-\mathrm{LaB}_{6}$; number of iterations $=5$. Results of the analyses were converted into weight percentages and atomic percentages.

Observations at the University of Silesia, Faculty of Earth Sciences, were carried out using an ESEM-XL 30 TMP (Philips/FEI) scanning electron microscope equipped with EDS (EDAX) detector.

ESEM was used to determine the REE-bearing mineral phases. On the basis of this method, preliminary data on chemical composition, shape of mineral phases, and succession of crystallization were determined. Qualitative EDS analyses of non-polished powder were performed only to determine mineral species.

\section{Chemical Composition}

The chemical composition of PG was determined based on the mean data, obtained according to research procedures based on PS 2001 methods of AAS, inductively coupled plasma-atomic emission spectrometry (ICP-AES), inductively coupled plasma-optical emission spectrometry (ICP-OES), and inductively coupled plasma-mass spectrometry (ICP-MS) X-ray fluorescence. The following equipment was used:

AAS-Atomic Absorption Spectrometry Thermo 3500 ICE (Thermo) with background correction for determination of metallic elements in flame and graphite cuvette.

XRF method, using the sample preparation equipment and the PW 2400 type fluorescent X-ray spectrometer from Philips.

ICP-AES sequence emission spectrometer ARL Model 3410 ICP (Fisons instruments).
ICP-OES spectrometer Plasm 40 from Perkin Elmer. ICP-MS using Elan 6100 apparatus from Perkin Elmer.

\section{Thermal Analysis}

Sample testing was conducted in a thermal analyzerNetzsch model STA 449 F3 Jupiter-by two measurement techniques, including the simultaneous analysis of DTA-TG (simultaneous signal recording from TG-DTA) which DTA and TG.

\section{Radiometric Analysis}

Summary activity of radionuclides in PG samples (potassium ${ }^{40} \mathrm{~K}$, radium ${ }^{226} \mathrm{Ra}$-, and thorium ${ }^{228} \mathrm{Th}$-) and, indirectly, the emission of gaseous radon ${ }^{222} \mathrm{Rn}$, was determined using the three-channel analyzer of radioactive contamination, AZAR; the obtained results were compared to normative specifications $[27,28]$. The measurements were made in accordance with the norm of the Institute of Building Technology $455 / 2010$ by utilizing the radionuclide contamination meter MAZUR 01. According to the norm of the institute regarding the natural radioactivity measurements of construction products, PI-MAZAR 01 is the only suggested meter for testing the suitability of construction products.

\section{Results and Discussion}

\section{Grain Size and Crystal Size Distribution}

Application of ultrasound turned out to be adequate in order to disperse all aggregates found in the sample, regardless of what caused lumping of the initial PG particles. Crystal size distribution of PG1 and PG2 samples that have been presented in Figs. 2 and 3 have a bimodal distribution, and the average diameter of PG1 crystals is about $211 \mu \mathrm{m}$, whereas of PG2 is $150 \mu \mathrm{m}$.

Basic parameters of crystal size distribution PG1: $d(0.1)$ $-29.911 \mu \mathrm{m}, d(0.5)-189.172 \mu \mathrm{m}, d(0.9)-414.747 \mu \mathrm{m}$, where:

$d(0.1)$ — value of diameter, where $10 \%$ of grains has a lower diameter than that value itself.

$d(0.5)$ - mean, value, which separates the distribution into two equal part, as well as the diameter, where $50 \%$ of grains has a lower diameter than that value itself.

$d(0.9)$ - is a value of diameter, where $90 \%$ of grains has a lower diameter than that value itself.

$D(4.3)$ - average diameter referenced to the volume.

Distribution parameters for PG2 samples were as follows: $d(0.1)-23.399 \mu \mathrm{m}, d(0.5)-126.164 \mu \mathrm{m}, d(0.9)$ $317.762 \mu \mathrm{m}$. 
Fig. 2 Grain size distribution of PG1 samples

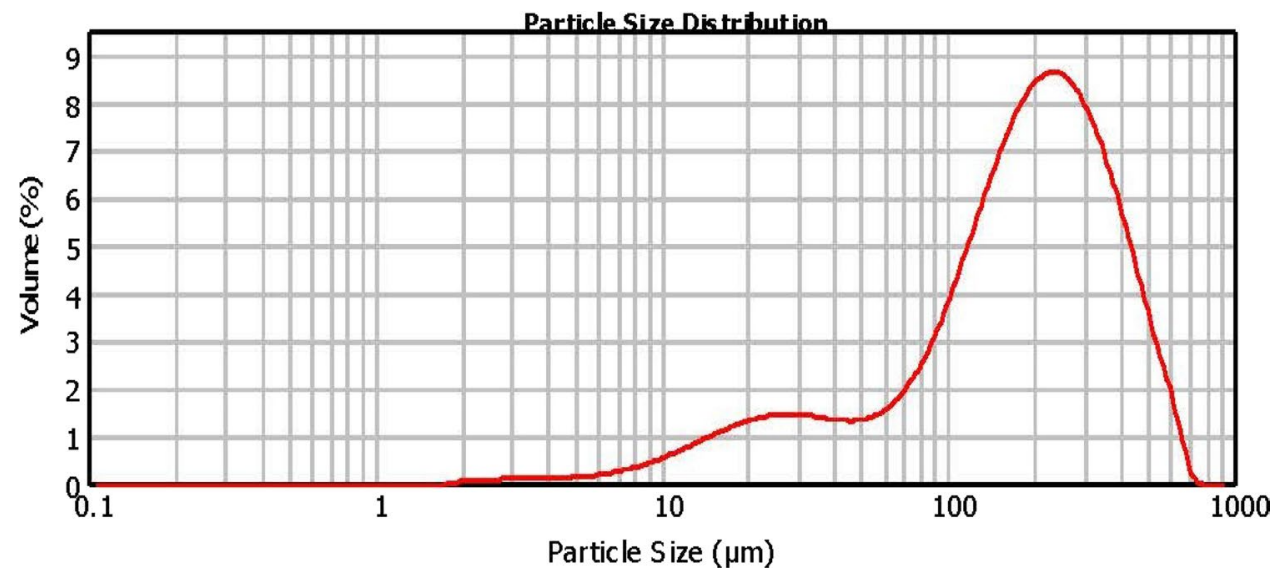

Fig. 3 Grain size distribution of PG2 samples

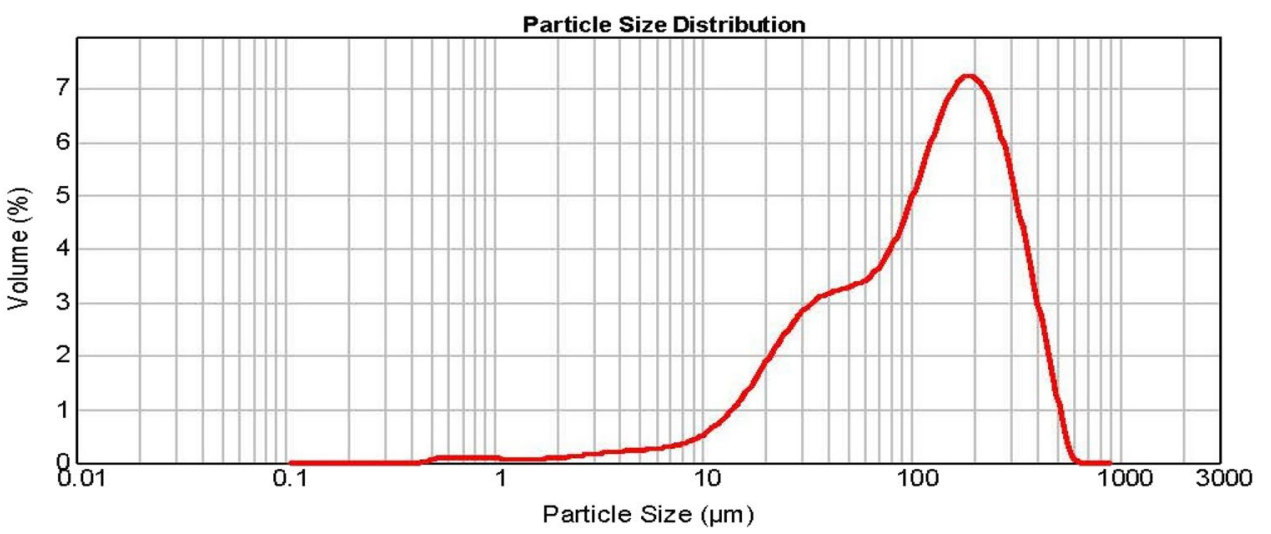

\section{X-Ray Powder Diffraction}

PG mineral composition is relatively diversified which was confirmed by XRD analyses. Data analysis was conducted using the computer program HighScore+ supplied with the current database ICSD and PDF4+. Diffractometric results suggest that gypsum and fluorapatite are the main components of PG (Fig. 4). Additionally, the following compounds were also detected: $\mathrm{SrSO}_{4}$ (celestine), $\mathrm{SiO}_{2}$ (quartz), $\mathrm{CaSO}_{4} \cdot 0.5 \mathrm{H}_{2} \mathrm{O}$ (bassanite), $\mathrm{Ca}_{6} \mathrm{Al}_{2}\left(\mathrm{SO}_{4}\right)_{3}(\mathrm{OH})_{12} \cdot 26 \mathrm{H}_{2} \mathrm{O}$ (ettringite), and $\mathrm{SrAl}_{3}\left(\mathrm{PO}_{4}\right)_{2}(\mathrm{OH})_{5} \cdot\left(\mathrm{H}_{2} \mathrm{O}\right)$ (goyazite). Based on the lines characteristic of monocaustic phosphate $\mathrm{Ca}\left(\mathrm{H}_{2} \mathrm{PO}_{4}\right)_{2} \cdot \mathrm{H}_{2} \mathrm{O}$, the presence of this acidic phosphate is apparent.

Quantitative analysis of mineral content was conducted using the roentgenography, comparing the intensity of the mineral line with the line of a clean mineral (model).

The percentage composition of the sample is shown in Fig. 5.

\section{Scanning Electron Microscopy (SEM)}

ESEM was used to determine the REE-bearing mineral phases. On the basis of this method, preliminary data on chemical composition, shape of mineral phases, and succession of crystallization were determined.

Based on the observation in backscattered electrons (BSE), it was found that phosphogypsum forms granules of up to $1 \mathrm{~mm}$ in size (mean 100-200 $\mu \mathrm{m}$ ) (Figs. 6, 7).

The BSE image (Fig. 6) shows agglomerated PG granules of various sizes. Brighter image contrast is a result of the stronger charging effect in the selected area. It is related to the thinner spray in that specific area and the imperfection of spraying itself. For areas marked with the pink table, a semiquantitative EDC analysis was conducted; the spectrum is shown next to it (Fig. 7). The conducted analysis showed mainly the presence of $\mathrm{Ca}, \mathrm{S}$, and $\mathrm{O}$, which suggests gypsum. Additionally the analysis found $\mathrm{Sr}, \mathrm{Si}, \mathrm{F}$, and $\mathrm{La}$ that may be built into the PG structure (Table 1).

During the research carried out at the University of Silesia, raw sample collected from the heap in Wizow contained strong-bonded granules (up to $2 \mathrm{~mm}$ in diameter) that were harder than the rest of the grains. In the BSE image, crystals were observed which show brighter contrast than the rest of the gypsum matrix (Fig. 8). Crystals which were acicular in appearance and had a total length up to $5 \mu \mathrm{m}$ have shown the presence of $\mathrm{SrSO}_{4}$ along with impurities such as $\mathrm{La}, \mathrm{Ce}$, and Nd. The EDS spectrum is suggestive of celestine. The 


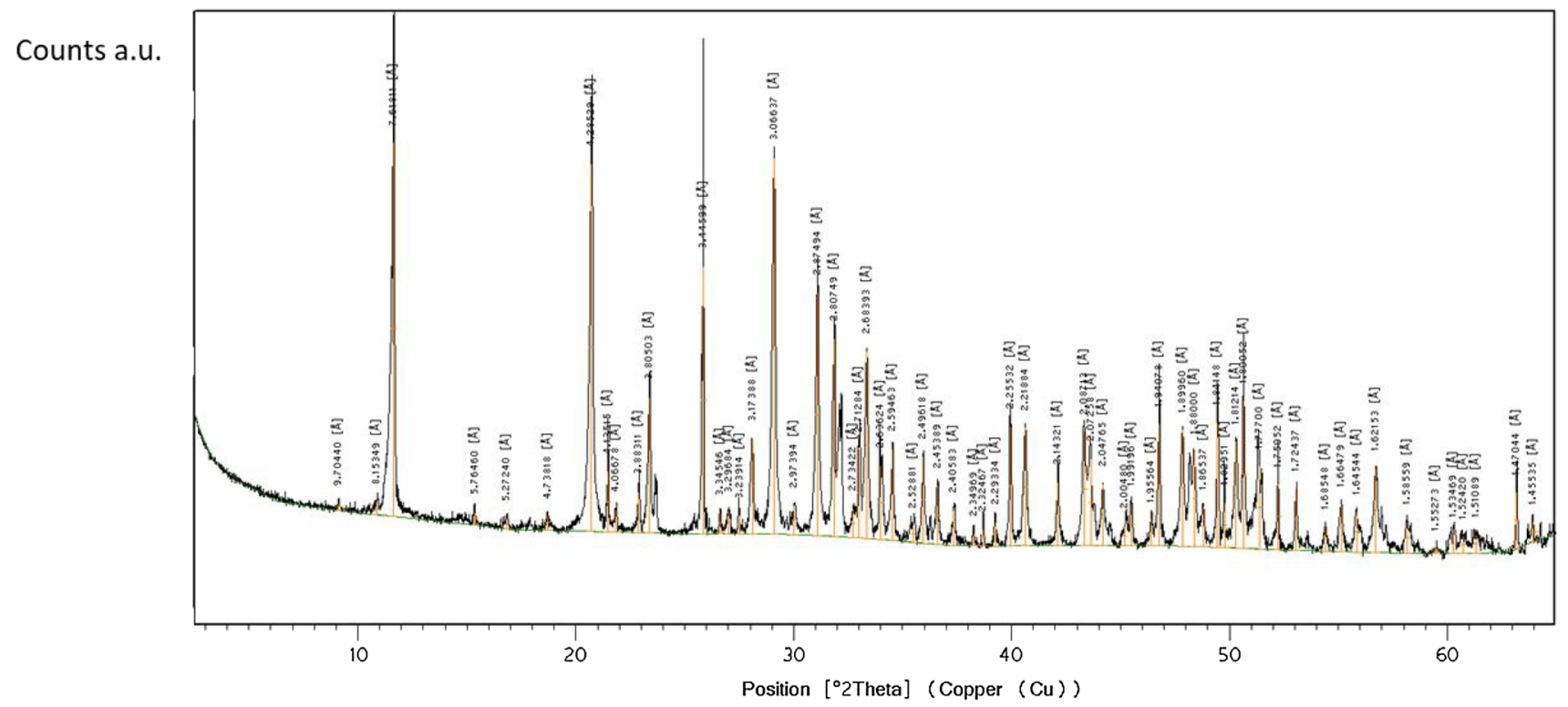

Fig. 4 Diffractogram of apatite phosphogypsum with standard series

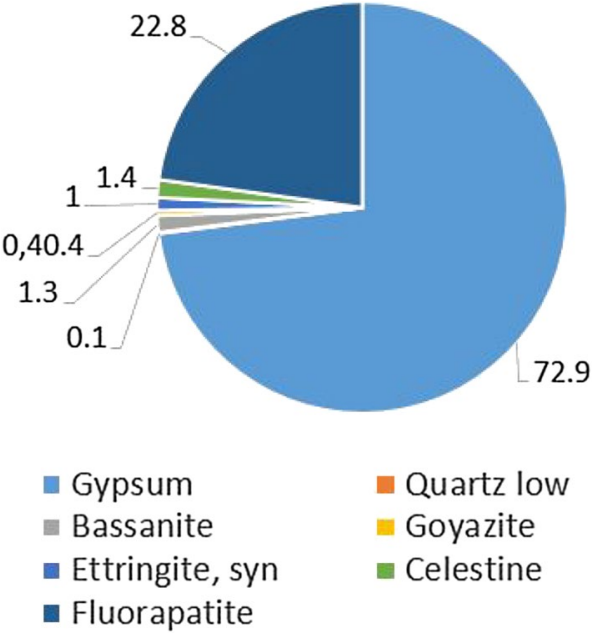

Fig. 5 Percentage shares of mineral phases in hard solids of phosphogypsum from Wizow

Ca peak is probably from the gypsum matrix. This is the first phase which contains REE.

Lanthanide form in PG is not clearly defined. However, it was experimentally ascertained that it is possible to extract REE from PG by extraction with mineral acids [17, 22, 29, 30]. REE in phosphogypsum may be in the form of compounds in combination of other cations, such as sulfates, phosphates, and fluorides. REE in the gypsum structure may be in-built within an elementary cell in the form of cations or anions connected to phosphorus or fluoride ions. REE may occur as isomorphic co-crystallates of REE and strontium [36].
Apatites from Kola Peninsula are rich in Sr; therefore, it is highly possible that the product of its dissolution in sulfuric acid may be celestine. As Sr has a strong affinity to REE, these elements easily create substitutions within the celestine structure which are opposite to the chemical structure of gypsum. This was proven in experiments conducted on apatite waste from Khibiny and Kovdor of Kola Peninsula [36]. The author indicated the existence of phosphate and sulfate $\mathrm{Sr}$ phases enriched in REE.

The second phase observed in the sample was strontium phosphate with REE (Fig. 9). In the EDS spectrum, as well as $\mathrm{Sr}$ and $\mathrm{P}, \mathrm{Ca}$ and $\mathrm{S}$ peaks are also present. This is presumably derived from gypsum, but can also come from a structure that is being discussed, as it may be a phase of goyazite structure.

In the sample, a residue of strontium-bearing apatite was present (Fig. 10), which was undissolved during the production process. The EDS spectrum did not indicate the presence of REE (Fig. 10).

\section{Analysis of Phosphogypsum Chemical Composition}

Table 2 presents chemical analyses of PG carried out by the authors and by Ancaster laboratory, Canada. PG2 is a sample which was intended to leaching tests to give lanthanides solution.

The utilization of apatite PG for bonding gypsum production is possible in the case of minimal lanthanide content, while the level of phosphates should not exceed $0.1 \%$ [30, 37]. 

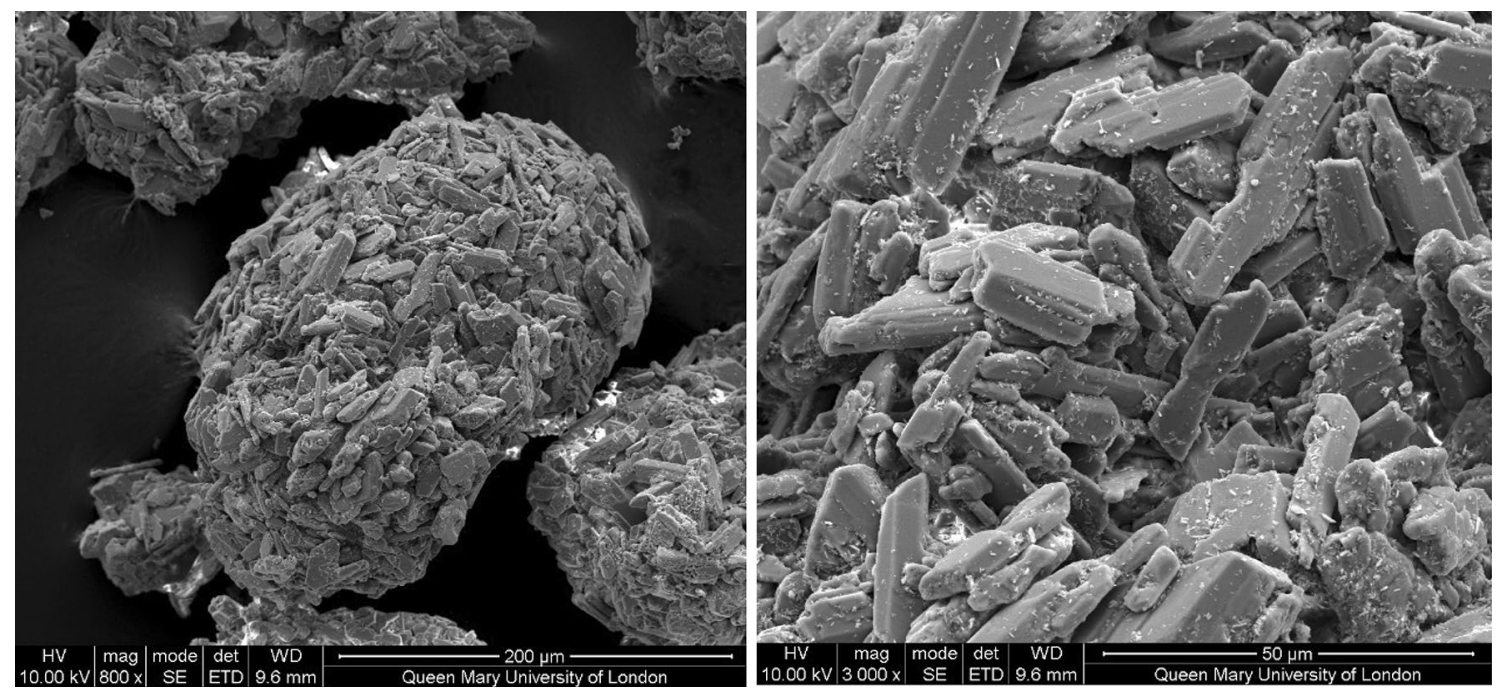

Fig. 6 BSE images of aggregate of PG sample (left) and an enlarged fragment of aggregate with gypsum crystals (right)
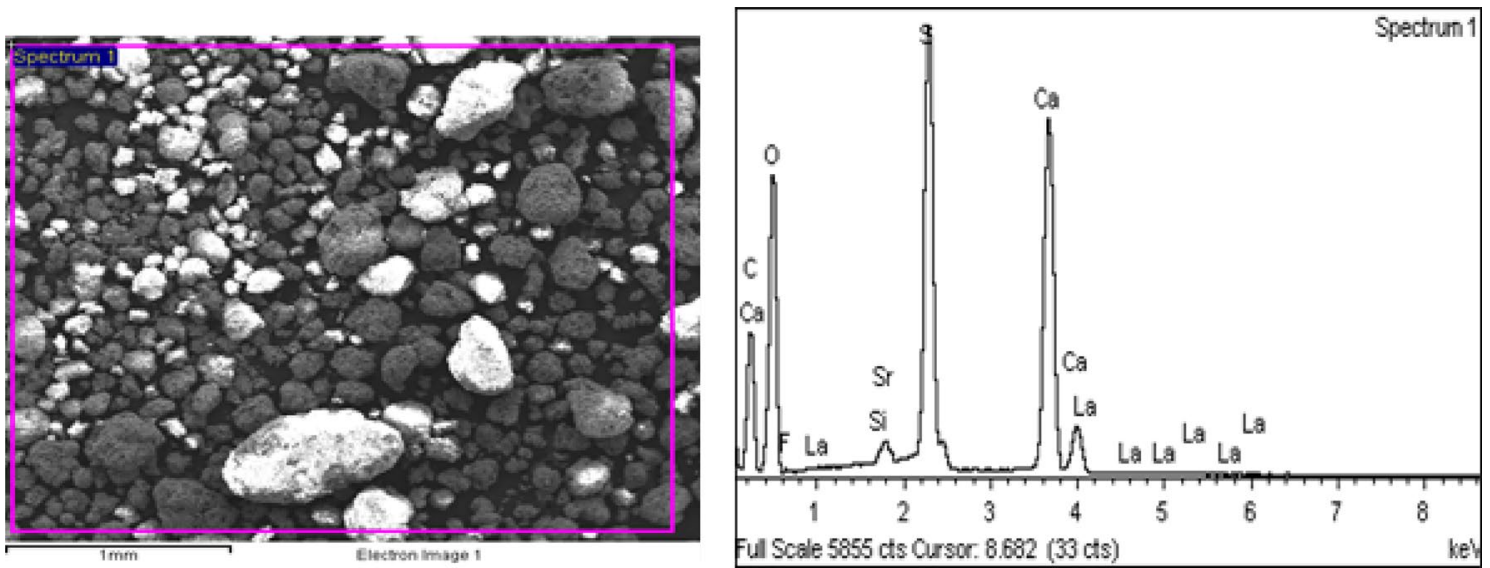

Fig. 7 BSE image of PG (pink frame is the field of semi-quantitative analysis) and EDS spectra of the field. (Color figure online)

Table 1 Chemical composition of PG on the basis on semiquantitative EDS analysis

\begin{tabular}{lrr}
\hline Element & wt\% & \multicolumn{1}{c}{ at.\% } \\
\hline $\mathrm{O}$ & 61.76 & 78.21 \\
$\mathrm{~F}$ & 1.49 & 1.59 \\
$\mathrm{Si}$ & 0.25 & 0.18 \\
$\mathrm{~S}$ & 15.88 & 10.03 \\
$\mathrm{Ca}$ & 19.03 & 9.62 \\
$\mathrm{Sr}$ & 1.58 & 0.36 \\
$\mathrm{La}$ & 0.01 & 0.00 \\
\hline
\end{tabular}

Results of the averaged samples of analyzed components obtained from the 12 drillings are in line with the mean values. The aggregate Ln concentration varies between 0.34 and $0.73 \%$ with the average of $0.45 \%$, where heavy lanthanides from Eu to Lu consist 3.9\% of the overall contents in phosphogypsum.

Filtration value of the samples taken for tests from various depths amounted to $8.35 \times 10^{-7}$ to $1.9 \times 10^{-8} \mathrm{~m} / \mathrm{s}$, whereas PG bulk density was $1.1-1.57 \mathrm{~g} / \mathrm{cm}^{3}$.

Differences in the PG filtration values are probably caused by compacting of PG as well as by the processes of cementation, associated with the movement of compounds washed out from the upper PG layers, such as phosphorus acid, fluorosilicate sodium, calcium and potassium sulfates and phosphates. This leads to filling up the space between the grains with chemical compounds and therefore joining of loose PG grains due to pressing together of sediments by the consecutive layers of the deposited wastes.

It is important and possible for industrial implementation to obtain a full value product in PG processing, such as binding 

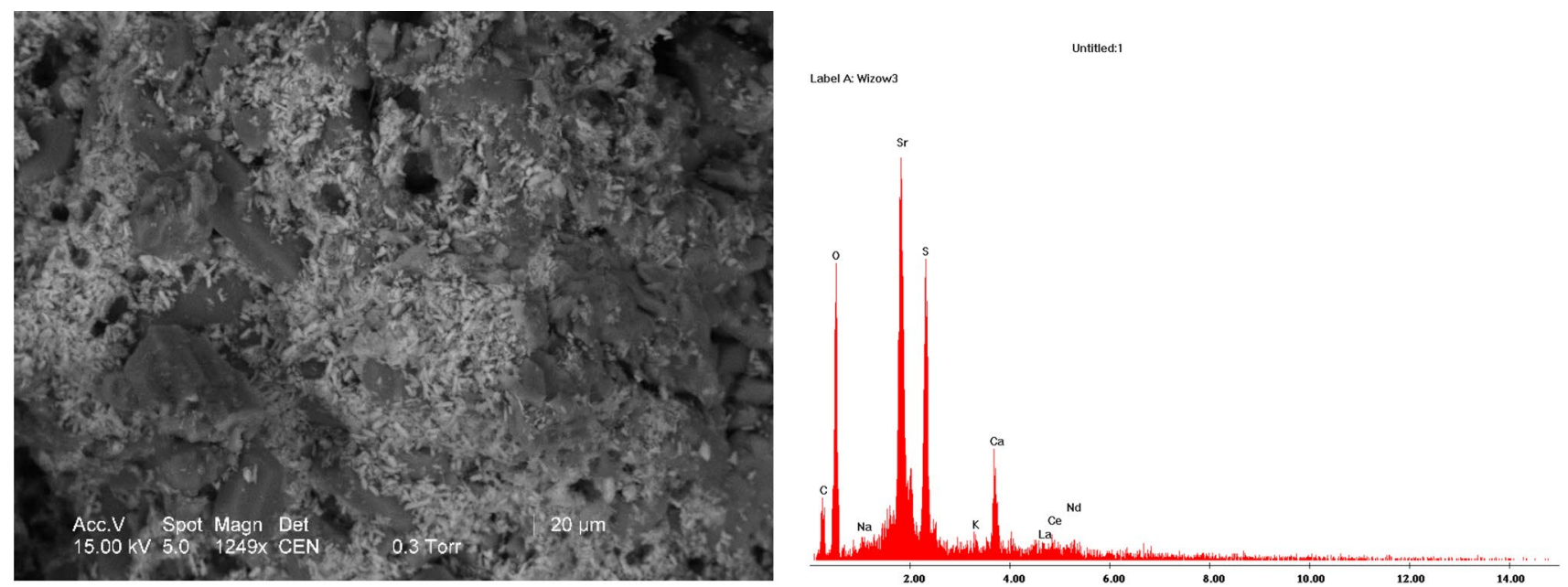

Fig. 8 BSE image of celestine (white) on the surface of gypsum (gray) and its EDS spectrum
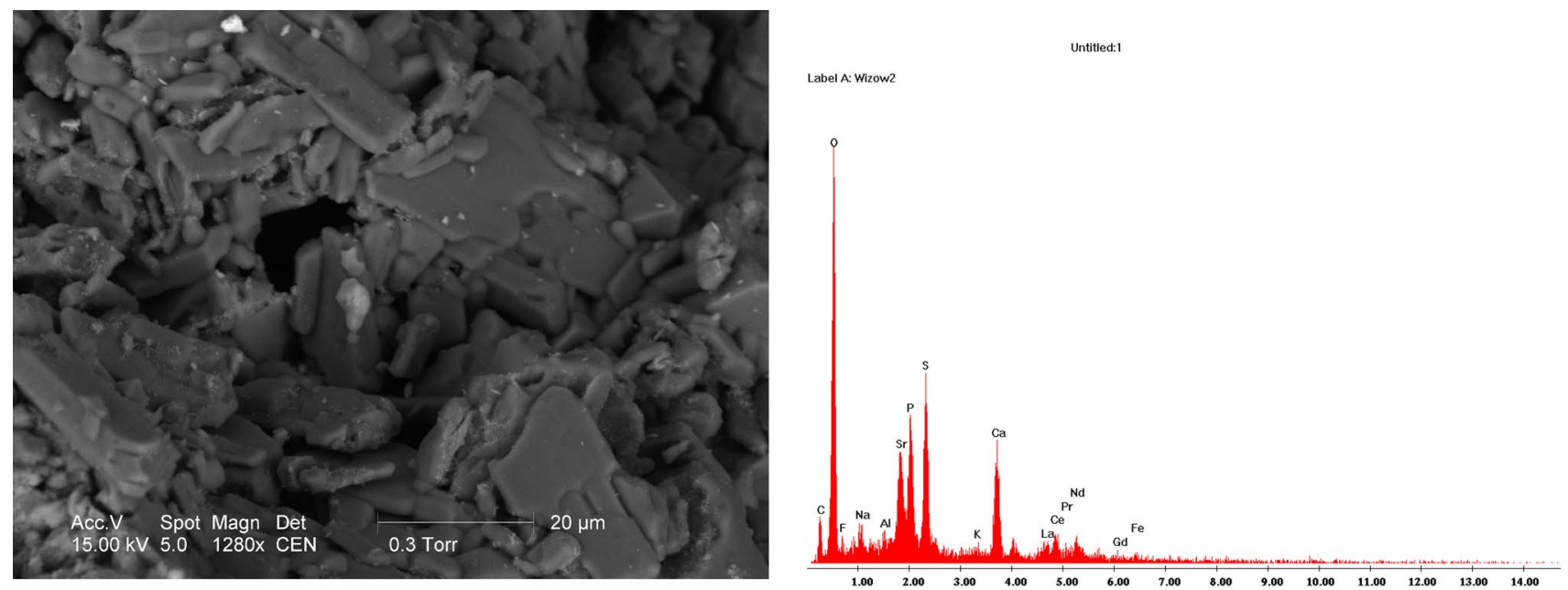

Fig. 9 BSE image of gypsum crystals (dark gray) with grains of REE-bearing Sr phosphate (light gray in the center) and its EDS spectrum (Ca and $\mathrm{S}$ peaks come from gypsum matrix)

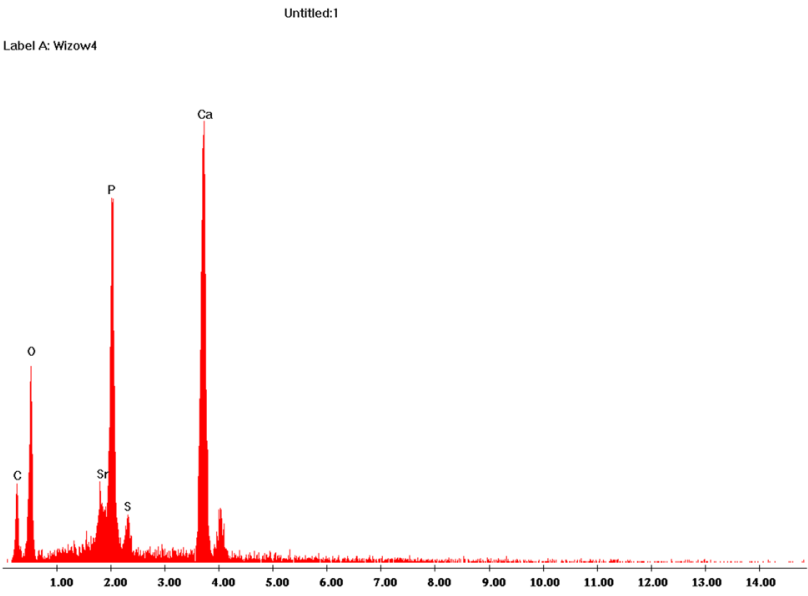

plaster, anhydrite cement, autoclave plaster, binders and construction elements [38-44], chalk fertilizer [45, 46], agriculture and fertilizers [41, 46-50], composite insulating materials [26], fillers for synthetic masses, paints and enamels [44], remediation agents for degraded areas enhancing soil acidity $[51,52]$, and road construction materials $[53,54]$.

\section{Thermogravimetric Analysis}

For the pure dihydrate, the dehydration process causes changes to the crystalline structure which follow the formula [55]:

$\mathrm{CaSO}_{4} \cdot 2 \mathrm{H}_{2} \mathrm{O}$ (monoclinic) $\rightarrow \mathrm{CaSO}_{4} \cdot 0.5 \mathrm{H}_{2} \mathrm{O}$ (monoclinic)

$\rightarrow \mathrm{CaSO}_{4} \mathrm{III}$ (pseudohexagonal) $\rightarrow \mathrm{CaSO}_{4} \mathrm{II}$ (orthorhombic)

Fig. 10 BSE image of an Sr-bearing apatite relic within PG from Wizow and its EDS spectrum 
Table 2 Composition of apatite PG samples from Wizow

\begin{tabular}{|c|c|c|c|c|}
\hline Component & Unit & Authors & Ancaster & PG2 \\
\hline $\mathrm{P}$ total & $\mathrm{mg} \mathrm{P} \mathrm{kg}^{-1}$ & $0.34-0.6$ & & 0.42 \\
\hline $\mathrm{P}$ available & $\mathrm{mg} \mathrm{P} \mathrm{kg}^{-1}$ & $0.3-0.57$ & & 0.17 \\
\hline K & mass $\%$ & $0.041-0.237$ & 0.0805 & 0.041 \\
\hline $\mathrm{Na}$ & $\operatorname{mass} \%$ & $0.079-0.834$ & 0.249 & 0.101 \\
\hline $\mathrm{F}$ & mass $\%$ & $0.34-0.42$ & & 0.34 \\
\hline $\mathrm{C}_{\text {org }}$ & $\operatorname{mass} \%$ & $1.14-1.20$ & & \\
\hline $\mathrm{CaO}$ & mass $\%$ & $29.6-31.4$ & 31.53 & 29.1 \\
\hline $\mathrm{SO}_{3}$ & mass $\%$ & $42.11-43.01$ & & 42.11 \\
\hline $\mathrm{Al}_{2} \mathrm{O}_{3}$ & mass $\%$ & $0.18-0.30$ & 0.304 & 0.21 \\
\hline $\mathrm{Fe}_{2} \mathrm{O}_{3}$ & $\operatorname{mass} \%$ & $0.06-0.20$ & 0.294 & 0.0 .93 \\
\hline $\mathrm{SiO}_{2}$ & mass $\%$ & $0.36-1.08$ & 1.34 & 0.5 \\
\hline $\mathrm{Sr}$ & $\operatorname{mass} \%$ & $1.30-1.45$ & 1.40 & 1.450 \\
\hline $\mathrm{Cu}$ & $\mathrm{mg} \mathrm{Cu} \mathrm{kg}{ }^{-1}$ & $17.0-32.6$ & 15.8 & 61.05 \\
\hline $\mathrm{Cd}$ & $\mathrm{mg} \mathrm{Cd} \mathrm{kg}{ }^{-1}$ & $1.31-1.43$ & & \\
\hline $\mathrm{Cr}$ & $\mathrm{mg} \mathrm{Cr} \mathrm{kg}{ }^{-1}$ & $4.06-5.40$ & & \\
\hline $\mathrm{Zn}$ & $\mathrm{mg} \mathrm{Zn} \mathrm{kg}{ }^{-1}$ & $9.4-66.0$ & $<30$ & 9.4 \\
\hline $\mathrm{Ni}$ & $\mathrm{mg} \mathrm{Ni} \mathrm{kg}{ }^{-1}$ & $1.3-2.0$ & & 1.5 \\
\hline $\mathrm{Pb}$ & $\mathrm{mg} \mathrm{Pb} \mathrm{kg}-1$ & $2.12-3.09$ & & \\
\hline $\mathrm{Mn}$ & mass $\%$ & $<0.0001$ & & \\
\hline $\mathrm{Ba}$ & mass $\%$ & & 0.054 & 0.0 \\
\hline $\mathrm{U}$ & $\mathrm{mg} \mathrm{U} \mathrm{kg}{ }^{-1}$ & & $<1.0$ & \\
\hline Th & $\mathrm{mg}$ Th $\mathrm{kg}^{-1}$ & & 10.0 & \\
\hline REE & mass $\% \mathrm{Ln}$ & $0.343-0.637$ & 0.447 & 0.4398 \\
\hline $\mathrm{La}$ & mass $\%$ & $0.13-0.15$ & 0.135 & 0.1247 \\
\hline $\mathrm{Ce}$ & mass $\%$ & $0.15-0.27$ & 0.198 & 0.1890 \\
\hline $\operatorname{Pr}$ & mass $\%$ & $0.015-0.024$ & 0.0197 & 0.0324 \\
\hline $\mathrm{Nd}$ & mass $\%$ & $0.05-0.09$ & 0.0665 & 0.0595 \\
\hline $\mathrm{Y}$ & mass $\%$ & $0.018-0.06$ & 0.0155 & 0.0192 \\
\hline $\mathrm{Sm}$ & mass $\%$ & $0.010-0.015$ & 0.0099 & 0.0051 \\
\hline Gd & mass $\%$ & $0.007-0.01$ & 0.0079 & 0.0048 \\
\hline Dy & mass $\%$ & $0.004-0.01$ & 0.0039 & 0.0022 \\
\hline $\mathrm{Eu}$ & mass $\%$ & $0.002-0.003$ & 0.0026 & 0.0023 \\
\hline $\mathrm{Er}$ & mass $\%$ & $0.0015-0.005$ & 0.0013 & 0.0004 \\
\hline $\mathrm{Tb}$ & mass $\%$ & & 0.0008 & \\
\hline Ho & $\operatorname{mass} \%$ & & 0.0006 & \\
\hline
\end{tabular}

In the DTA curve for pure gypsum, there are two clearly visible endothermic effects

- first, at the temperature of about $160{ }^{\circ} \mathrm{C}$ connected with transformation of dihydrate into hemihydrate $(\alpha$ or $\beta)$, and

- second, at the temperature of about $200{ }^{\circ} \mathrm{C}$, the transformation of hemihydrate into the phase of anhydrous sulfate $\mathrm{CaSO}_{4}$-III $(\alpha$ or $\beta)$.

With further temperature increase to $350{ }^{\circ} \mathrm{C}$, an exothermic effect is observed for hemihydrate $\beta$ which is connected to phase transformation:
$\beta-\mathrm{CaSO}_{4} \cdot-\mathrm{III} \rightarrow \mathrm{CaSO}_{4}$-II

Whereas for $\alpha$-hemihydrate, this effect occurs earlier, at temperatures of about $220{ }^{\circ} \mathrm{C}$ :

$\alpha-\mathrm{CaSO}_{4} \cdot-\mathrm{III} \rightarrow \mathrm{CaSO}_{4}$-II

DTA and TG examinations were performed for two PG samples at an interval of $20 \div 600{ }^{\circ} \mathrm{C}$. During heating of the PG sample, $\mathrm{CaSO}_{4} \cdot 2 \mathrm{H}_{2} \mathrm{O}$ undergoes gradual dehydration, first to hemihydrate and subsequently to anhydrous form. The DTA curve for PG samples allows a quality assessment of chemical processes that occur in samples as a result of temperature changes. An intensive dehydration of dihydrate into hemihydrate occurs at a temperature range from 130 to $190^{\circ} \mathrm{C}$ for the TG curve (Fig. 11) and from 120 to $185^{\circ} \mathrm{C}$ for DTA curve. In a DTA curve for PG1, there are two visible endothermic peaks of different intensities. The maximum of the first one is at $148.6{ }^{\circ} \mathrm{C}$ and the second one is at $165.4{ }^{\circ} \mathrm{C}$. An exothermic effect occurs at about $420^{\circ} \mathrm{C}$. In PG2, these are at $142.9,162.8$, and $350^{\circ} \mathrm{C}$, respectively. These values differ from the values for pure gypsum, with the high probability that they result from impurities in PG samples. The PG2 sample was taken from the surface layer of the pile, while the PG1 sample was from $1 \mathrm{~m}$ below the pile surface. The washout into deeper layers of the landfill causes salinity to increase with depth.

TG curves allow the quantitative assessment of these processes (they show changes in sample mass at different temperatures). Based on a DTA and TG curve analysis, it was claimed that sample PG1 contained about $19.80 \% \mathrm{H}_{2} \mathrm{O}$, and $\mathrm{PG} 2$ about $19.31 \% \mathrm{H}_{2} \mathrm{O}$.

\section{Radiometric Analysis-Calculating the Radiological Effect}

Calculation of the radiological effects was carried out based on the formula 1 . There are two accepted qualifying indicators considering radioactive activity: $f_{1}$ and $f_{2}$, where

$f_{1}$-informs about exposure to gamma radiation by natural radionuclides (see Table) which occur in environmental samples of mineral origin,

$f_{2}$ - informs about radium Ra-226 content which is a vernacular radon isotope and additionally indirectly indicates a level of exposure to alpha radon $\mathrm{Rn}-226$ radiation and its short-lived derivatives (risk for lung epithelium). $\mathrm{kg}$

Safety conditions are met when $f_{1} \leq 1.2$ and $f_{2} \leq 240 \mathrm{~Bq} /$

$$
\begin{gathered}
f_{1}=S_{\mathrm{K}} /(3000 \mathrm{~Bq} / \mathrm{kg})+S_{\mathrm{Ra}} /(300 \mathrm{~Bq} / \mathrm{kg})+S_{\mathrm{Th}} / \\
(200 \mathrm{~Bq} / \mathrm{kg}) \text { and } f_{2} \leq S_{\mathrm{Ra}}
\end{gathered}
$$


Fig. 11 Thermogram of sample PG1. TG and DTA curves shape

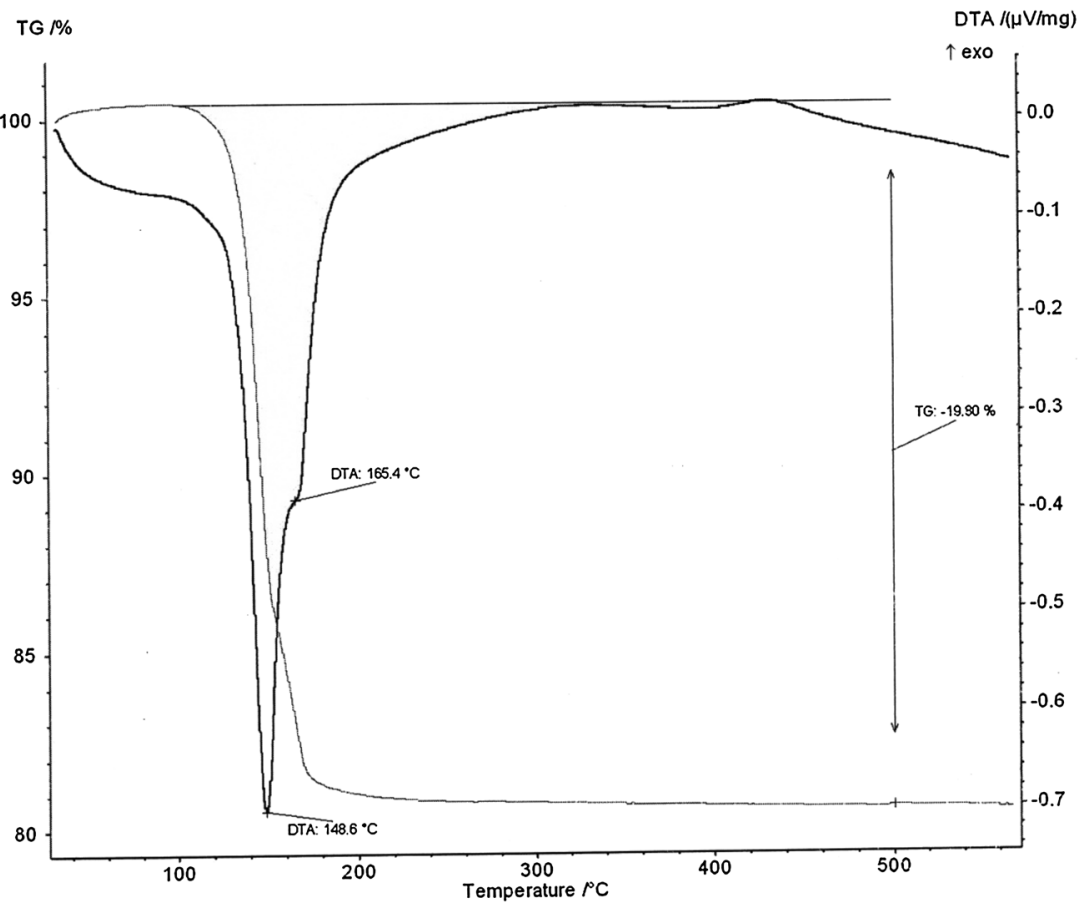

Table 3 Radionuclides in examined samples of PG

\begin{tabular}{lllll}
\hline Sample & Radionuclide & Series & $\begin{array}{l}\text { Activity concen- } \\
\text { tration }(S)[\mathrm{Bq} / \mathrm{kg}]\end{array}$ & $\begin{array}{l}\text { Analytical } \\
\text { error }[\mathrm{Bq} / \\
\mathrm{kg}]\end{array}$ \\
\hline$P G 1$ & $\mathrm{~K}-40$ & - & $<20$ & - \\
& $\mathrm{Ra}-226$ & $\mathrm{U}-\mathrm{Ra}$ & 80.5 & 20.4 \\
& $\mathrm{Th}-228$ & $\mathrm{Th}$ & 76.2 & 6.8 \\
$P G 2$ & $\mathrm{~K}-40$ & - & $<22$ & - \\
& $\mathrm{Ra}-226$ & $\mathrm{U}-\mathrm{Ra}$ & 72.8 & 18.6 \\
& $\mathrm{Th}-228$ & $\mathrm{Th}$ & 86.8 & 7.6 \\
\hline
\end{tabular}

where $S_{\mathrm{K}}, S_{\mathrm{Ra}}$, and $S_{\mathrm{Th}}$-concentrations of potassium K-40, radium $\mathrm{Ra}-226$, and thorium Th-228 in Bq/kg.

For the maximum values specified in Table 3 , the calculated indicators are $f_{1}=0.71$ and $f_{2}=80.5 \mathrm{~Bq} / \mathrm{kg}$; therefore, safety conditions for apatite PG as a potential building material are met.

For a comparison, concentrations of natural radionuclides for Polish soils are listed below. The mean values for Poland and ranges of concentrations of four radionuclides in 2012 are as follows [56]:

- potassium ${ }^{40} \mathrm{~K}$ : mean-415 Bq/kg; range-63-924 Bq/ $\mathrm{kg}$;

- radium ${ }^{226} \mathrm{Ra}$ : mean-24.8 Bq/kg; range-4.3-128.3 Bq/ $\mathrm{kg}$;

- thorium ${ }^{228} \mathrm{Th}$ : mean-23.8 $\mathrm{Bq} / \mathrm{kg}$; range-4.1$101.7 \mathrm{~Bq} / \mathrm{kg}$.

\section{Tests of Lanthanide Leaching}

Thorough tests conducted by the authors under the previous experiments have shown that the phosphogypsum apatite may be considered as a potential raw material for lanthanides recovery.

Leaching of PG with sulfuric acid allows the removal of the lanthanides as wells as other noxious contaminants that disallow PG utilization for the purposes of building construction.

Dried in $105^{\circ} \mathrm{C}$ for a period of $2 \mathrm{~h}$, phosphogypsum PG2 was subjected to leaching using sulfuric acid of concentration 10 and $15 \%$ in room temperature of $20{ }^{\circ} \mathrm{C}$. The ratio of liquid to solid phases was 1:3. To accomplish the above, a sample of $50 \mathrm{~g}$ phosphogypsum was taken, when introduced to a glass beaker it was doused in sulfuric acid of adequate concentration, then it was subjected to leaching without heating for a period of $4 \mathrm{~h}$. The morphology of the PG2 crystals that was subjected to tests has been presented in Fig. 6.

The suspension then was subjected to vacuum filtration and washing the suspension three times with distilled water in total amount equal to double the mass of the used sample of the phosphogypsum. The filtrate was collected separately as were the washings. The process of washing was conducted in several stages using in each stage of washing double repulpation of the filter cake. Each time the repulpated suspension was filtered. The suspension after washing and drying in $105^{\circ} \mathrm{C}$ was subjected to chemical analysis. Based on the conducted analyses, the lanthanides leaching fraction in relation to their 
Table 4 Phosphogypsum analysis

\begin{tabular}{llcll}
\hline Component & Unit & $\mathrm{PG} 2$ & $\mathrm{PG}_{10 \% \mathrm{H}_{2} \mathrm{SO}_{4}}$ & $\mathrm{PG}_{15 \% \mathrm{H}_{2} \mathrm{SO}_{4}}$ \\
\hline $\mathrm{pH}_{\mathrm{H}_{2} \mathrm{O}}$ & & 2.83 & & \\
$P_{\text {total }}$ & $\mathrm{mg} \mathrm{P} \mathrm{kg}^{-1}$ & 0.42 & 0.38 & 0.37 \\
$P_{\text {available }}$ & $\mathrm{mg} \mathrm{P} \mathrm{kg}^{-1}$ & 0.17 & 0.14 & 0.12 \\
$\mathrm{Ln}$ & mass \% & 0.44 & 0.213 & 0.216 \\
$\mathrm{~F}$ & mass \% & 0.37 & 0.30 & 0.27 \\
$\mathrm{Al}_{2} \mathrm{O}_{3}$ & mass \% & 0.18 & 0.012 & 0.10 \\
$\mathrm{Fe}_{2} \mathrm{O}_{3}$ & mass \% & 0.061 & 0.055 & 0.050 \\
$\mathrm{Na}_{\mathrm{K}}$ & mass \% & 0.082 & 0.075 & 0.074 \\
$\mathrm{SiO}_{2}$ & mass \% & 0.045 & 0.040 & 0.040 \\
$\mathrm{Sr}_{\mathrm{CaO}}$ & mass \% & 0.002 & & \\
$\mathrm{SO}_{3}$ & mass \% & 1.45 & 1.45 & 1.44 \\
$\mathrm{Zn}$ & mass \% & 30.1 & & \\
\hline
\end{tabular}

Table 5 Degree of lanthanide extraction efficiency

\begin{tabular}{lll}
\hline Leaching & $10 \% \mathrm{H}_{2} \mathrm{SO}_{4}$ & $15 \% \mathrm{H}_{2} \mathrm{SO}_{4}$ \\
\hline Extraction efficiency $\%$ & 51.5 & 50.9 \\
\hline
\end{tabular}

content in raw phosphogypsum was determined. The results are shown in Tables 4 and 5.

It was determined that using $10 \%$ rather than $15 \%$ sulfuric acid was more effective in the process of leaching. By recrystallizing the PG using a sulphuric acid, it is realistic to extract only about $50 \%$ of the rare earth contained in the phosphogypsum accumulated in the heap.

Concentration of lanthanides in the obtained solution after recrystallization is relatively low, around $1 \div 3 \mathrm{~g} \mathrm{Ln}_{2} \mathrm{O}_{3}$ per $1 \mathrm{dm}^{3}$. The lanthanide solution may be considered as a starting raw material for the separate processing procedure.

Farther processing of the obtained solution containing lanthanides proceeds in accordance with the procedures presented in [57]. The obtained PG, after the filtration and washing processes, was then subjected to calcination. Next, the sample was tested according with the PN-EN 13279-2:2006 norms "Binding materials." The obtained material had characteristics of the following parameters: ratio water/binder $=0.74 \pm 0.02$, initial binding time $250 \mathrm{~s}$, resistance to bending $2.85 \pm 0.2 \mathrm{~N} / \mathrm{mm}^{2}$, and resistance to compression $6.5 \pm 0.2 \mathrm{~N} / \mathrm{mm}^{2}$. Eruptions and blooms in the structure of the obtained binding gypsum have not been observed.

\section{Conclusions}

PG waste dumps from the former chemical plant Wizow, which collects waste from the production of phosphoric acid made by wet methods from apatite raw materials, contains dihydrate calcium sulfate as a main compound and impurities such as phosphates, sulfates, fluorides, heavy metals, aluminum, iron, silica, and strontium compounds, as well as REE and naturally occurring radionuclides. This waste is described by code 060980 and for many years it has been a burden for the environment. The waste contains an admissible level of radioactive chemical elements for building materials. The concentration of natural radionuclides in PG is close to the values which characterize Polish soils.

PG samples contain an overall amount of REE in the interval of $0.343-0.637 \%$ by mass; the main components of lanthanides are elements such as $\mathrm{Ce}, \mathrm{Ln}, \mathrm{Pr}, \mathrm{Nd}$, and Y. Their extraction, despite the slight share in PG, can result in a significant amount of REE being produced and other measurable effects in processing of huge amounts of landfill waste, connected with the necessity to solve ecological problems. These effects are due to the removal of REE and, in the meantime, cleaning the main PG bulk from other accompanying impurities. Hence, apatite PG can be used for the production of binding plaster.

Lanthanide extraction tests from apatite phosphogypsum utilizing sulphuric acid have shown the efficiency level to be at about $50 \%$ in relation to $\mathrm{Ln}_{2} \mathrm{O}_{3}$ content in the initial raw material. Viability of the investment will be decided by the economy and the price of raw materials, building materials, and energy factors. Due to lanthanides usefulness in modern technologies, it should be predicted that their cost will rise. Moreover, elimination of difficult to estimate environmental costs of phosphogypsum storage should be taken into account as well.

Considering the actual level of knowledge, which is the result of previous and ongoing research works, a hypothesis can be formulated that for the specified market prices for REE and using the right technological solutions, the processing of apatite PG can be economically profitable. Besides these conditions, an important factor which determines the efficiency of such a project is obtaining market products of a standard value as a result of PG processing: binding plaster, anhydrite cement, autoclave plaster, binders, building elements, chalk fertilizer, composite isolating materials, fillers for synthetic masses, dyes and enamels, and using PG for the remediation of degraded terrains, in agriculture (enhancing soil acidity) and in road construction. Designing innovatory and innovative technologies for PG processing provides a chance to eliminate landfills by processing it into useful trade products. 
Acknowledgements We thank Dr. Zofia Luklinska from the Queen Mary NanoVision Centre for microscopy analysis, and Professor Jozef Hoffmann, Faculty of Chemistry, Wroclaw University of Science and Technology for thermal analysis. The work was carried out within the scientific funds allocated for statutory activities $0401 / 0200 / 17$ by the Ministry of Science and Higher Education.

Open Access This article is distributed under the terms of the Creative Commons Attribution 4.0 International License (http://creativeco mmons.org/licenses/by/4.0/), which permits unrestricted use, distribution, and reproduction in any medium, provided you give appropriate credit to the original author(s) and the source, provide a link to the Creative Commons license, and indicate if changes were made.

\section{References}

1. Guyonnet, D., Planchon, M., Rollat, A., Escalon, V., Tuduri, J., Charles, N., Vaxelaire, S., Dubois, D., Fargier, H.: Material flow analysis applied to rare earth elements in Europe. J. Clean. Prod. 107, 215-228 (2015)

2. Hatch, G.P.: Dynamics in the global market for rare earths. Elements 8, 341-346 (2012)

3. Goodenough, K.M., Schilling, J., Jonsson, E., Kalvig, P., Charles, N., Tuduri, J., Deady, E.A., Sadeghi, M., Schiellerup, H., Muller, A., Bertrand, G., Arvanitidis, N., Eliopoulos, D.G., Shaw, R.A., Thrane, K., Keulen, N.: Europe's rare earth element resource potential: an overview of REE metallogenetic provinces and their geodynamic setting. Ore Geol. Rev. 72, 838-856 (2016)

4. Jordens, S.A., Cheng, Y.P., Waters, K.E.: A review of the beneficiation of rare earth element bearing minerals. Miner. Eng. 41, 97-114 (2013)

5. Nieto, A., Iannuzzi, M.: Supply-and-demand geoeconomic analysis of mineral resources of rare earth elements in the United States. Miner. Eng. 64, 74-82 (2012)

6. Haque, N., Hughes, A., Lim, S., Vernon, C.: Rare earth elements: overview of mining, mineralogy, uses, sustainability and environmental impact. Resources 3, 614-635 (2014)

7. Commission of European Communities. Communication on the 2017 list of Critical Raw Materials for the EU (COM 490, 2017)

8. Binnemans, K., Jones, P.T., Blanpain, B., Van Gerven, T., Pontikes, Y.: Towards zero-waste valorisation of rare-earth-containing industrial process residues: a critical review. J. Clean. Prod. 99, 17-38 (2015)

9. Kranert, I.M., Fischer, I.K., Böhme, D.I.L., Schetula, V.: Rohstoffsicherheit in Baden-Württemberg-Abfälle aus Leuchtstoffröhren und Gasentladungslampen als Quelle von seltenen Erden (Universität Stuttgart, Stuttgart, 2013)

10. Li, J.Y., Liu, Z.D., Zhao, W.Z., Masud, M.M., Xu, R.K.: Alkaline slag is more effective than phosphogypsum in the amelioration of subsoil acidity in an Ultisol profile. Soil Tillage Res. 149, 21-32 (2015)

11. Sinha, S., Meshram, P., Pandey, B.D.: Metallurgical processes for the recovery and recycling of lanthanum from various resourcesa review. Hydrometallurgy 160, 47-59 (2016)

12. Bandara, H.D., Field, K.D., Emmert, M.H.: Rare earth recovery from end-of-life motors employing green chemistry design principles. Green Chem. 18, 753-759 (2016)

13. Polyakov, E.G., Sibilev, A.S.: Recycling rare-earth-metal wastes by pyrometallurgical methods. Metallurgist 59, 368-373 (2015)

14. Goralczyk, S., Uzunow, E.: The recovery of yttrium and europium compounds from waste materials. Arch. Environ. Prot. 39, 107-114 (2013)
15. Blissett, R.S., Smalley, N., Rowson, N.A.: An investigation into six coal fly ashes from the United Kingdom and Poland to evaluate rare earth element content. Fuel 119, 236-239 (2014)

16. Kashiwakura, S., Kumagai, Y., Kubo, H., Wagatsuma, K.: Dissolution of rare earth elements from coal fly ash particles in a dilute $\mathrm{H}_{2} \mathrm{SO}_{4}$ solvent. Open J. Phys. Chem. 3, 69-75 (2013)

17. Podbiera-Matysik, K., Gorazda, K., Wzorek, Z.: Potential management of waste phosphogypsum with particular focus on recovery of rare earth metals. Pol. J. Chem. Technol. 17, 55-61 (2015)

18. Koopman, C., Witkamp, G.J.: Extraction of lanthanides from the phosphoric acid production process to gain a purified gypsum and valuable lanthanide by-product. Hydrometallurgy 58, 51-60 (2000)

19. Becker, P.: Phosphates and Phosphoric Acid. Marcel Dekker Inc., New York (1989)

20. Grzmil, B., Kic, B., Żurek, O., Kubiak, K.: Studies on the transformation of calcium sulphate dihydrate to hemihydrate in the wet process phosphoric acid production. Pol. J. Chem. Technol. 14, 80-87 (2012)

21. Jarosinski, A., Kowalczyk, J., Mazanek, C.: Development of the Polish wasteless technology of apatite phosphogypsum utilization with recovery of rare-earths. J. Alloys Compd. 200, 147-150 (1993)

22. Zielinski, S., Szczepanik, A., Buca, M., Kunecki, M.: Recovery of lanthanides from Kola apatite in phosphoric-acid manufacture. J. Chem. Technol. Biotechnol. 56, 355-360 (1993)

23. Kulczycka, J., Kowalski, Z., Smol, M., Wirth, H.: Evaluation of the recovery of Rare Earth Elements (REE) from phosphogypsum waste-case study of the Wizow Chemical Plant (Poland). J. Clean. Prod. 113, 345-354 (2016)

24. Habashi, F.: The recovery of the lanthanides from phosphate rock. J. Chem. Technol. Biotechnol. 35A, 5-14 (1985)

25. Heffer, P., Prud'homme, M.: Fertilizer Outlook 2014-2018. 82nd IFA annual conference, Sydney, 26-28 May (2014)

26. Tayibi, H., Gasco, C., Navarro, N., Lopez-Delgado, A., Choura, M., Alguacil, F.J., Lopez, F.A.: Radiochemical characterization of phosphogypsum for engineering use. J. Environ. Prot. 2, 168-174 (2011)

27. Cabinet of Poland: Regulations of January 2, 2007 on the requirements for the content of natural radioactive isotopes of potassium $\mathrm{K}-40, \mathrm{Ra}-226$ radium and thorium Th-228 in raw materials used in buildings designed to accommodate people and livestock, as well as industrial waste used in construction, and control of these isotopes). Dz. U. 2007 nr 4, poz. 29 (2007) (in Polish)

28. Zapotoczna-Sytek, G.: Natural radioactivity of construction products, including autoclaved cellular concrete (ABK). Przeglad budowlany 7-8, 39-42 (2012) (in Polish)

29. Lokshin, E.P., Tareeva, O.A.: Recovery of lanthanides from extraction phosphoric acid produced by the dihydrate process. Russ. J. Appl. Chem. 83, 951-957 (2010)

30. Kijkowska, R., Kowalczyk, J., Mazanek, C., Pawłowska-Kozińska, D.: Apatite phosphogypsum - raw material for the production of rare earths and gypsum. Wyd. Geologiczne, Warszawa (1988) (in Polish)

31. Valancius, Z., Nizeviciene, D., Leskeviciene, V., Kybartiene, N.: Influence of the technological parameters on the structure and properties of hemi-hydrate phosphogypsum. Ceram.-Silik. 49, 120-125 (2005)

32. Krishnamurthy, N., Gupta, C.K.: Extractive Metallurgy of Rare Earths. CRC Press, Boca Raton (2015)

33. Lokshin, E.P., Tareeva, O.A.: Production of high-quality gypsum raw materials from phosphogypsum. Russ. J. Appl. Chem. 88, 567-573 (2015)

34. Wang, L., Long, Z., Huang, X., Yu, Y., Cui, D., Zhang, G.: Recovery of rare earths from wet-process phosphoric acid. Hydrometallurgy 101, 41-47 (2010) 
35. Lokshin, E.P., Tareeva, O.A.: Processing of phosphodihydrate to separate rare-earth elements and obtain gypsum free from phosphates and fluorides. Russ. J. Appl. Chem. 88, 567-573 (2011)

36. Samonov, A.E.: New data on mineral forms of rare metals in phosphogypsum wastes. Doklady Akademii Nauk, Geochem. 40, 234-237 (2011)

37. Kijkowska, R., Kowalczyk, J., Mazanek, C., Mikolajczyk, T., Pawlowska-Kozinska, D.: Rare earth elements from Kola apatite phosphogypsum. Phosphorus Potassium 163, 22-26 (1989)

38. Altun, İA., Sert, Y.: Utilization of weathered phosphogypsum as set retarder in Portland cement. Cem. Concr. Res. 34, 677-680 (2004)

39. Degirmenc, N.: Utilization of phosphogypsum as raw and calcined material in manufacturing of building products. Constr. Build. Mater. 22, 1857-1862 (2008)

40. Leskeviciene, V., Nizeviciene, D.: Investigation of anhydrite cement produced from phosphogypsum. Cement Wapno Beton 80, 362-369 (2013)

41. Tayibi, H., Choura, M., Lopez, F.A., Alguacil, F.J., Lopez-Delgado, A.: Environmental impact and management of phosphogypsum (review). J. Environ. Manag. 90, 2377-2386 (2009)

42. Yang, J., Liu, W., Zhang, L., Xiao, B.: Preparation of load-bearing building materials from autoclaved phosphogypsum. Constr. Build. Mater. 23, 687-693 (2009)

43. Zhou, J., Yu, D., Shu, Z., Li, T., Chen, Y., Wang, Y.: A novel twostep hydration process of preparing cement-free non-fired bricks from waste phosphogypsum. Constr. Build. Mater. 73, 222-228 (2014)

44. Zielinski, M.: Utilization of phosphogypsum in the aspect of environmental protection. Przem. Chem. 85, 478-482 (2006) (in Polish)

45. Lewandowski, M., Gorecki, H., Zieba, S., Kuzko, A.: Method of utilization of phosphogypsum for fertilizer chalk under conditions of chemical plants Police. Przem. Chem. 63, 406-409 (1984) (in Polish)

46. Gorecki, H., Patrzek, F.: Model study of single-stage conversion of phosphogypsum to fertilizer chalk. Przem. Chem. 65, 190-192 (1986) (in Polish)
47. Alcordo, I.S., Rechcigl, J.E.: Phosphogypsum in agriculture: a review. Adv. Agron. 49, 55-118 (1993)

48. Delgado, A., Uceda, I., Andreu, L., Kessem, S., Del Campillo, M.C.: Fertilizer phosphorus recovery from gypsum-amended, reclaimed calcareous marsh soils. Arid Land Res. Manag. 16, 319-334 (2002)

49. Degirmenci, N., Okucu, A., Turabi, A.: Application of phosphogypsum in soil stabilization. Build. Environ. 42, 3393-3398 (2007)

50. Mays, D.A., Mortvedt, J.J.: Crop response to soil applications of phosphogypsum. J. Environ. Qual. 15, 78-81 (1986)

51. Elloumi, N., Belhaj, D., Mseddi, S., Zouari, M., Abdallah, F.B., Woodward, S., Kallel, M.: Response of Nerium oleander to phosphogypsum amendment and its potential use for phytoremediation. Ecol. Eng. 99, 164-171 (2017)

52. Siuta, J.: Waste in land reclamation. Inz. Ekolog. 19, 59-78 (2007) (in Polish)

53. Shen, W., Zhou, M., Ma, W., Hu, J., Cai, Z.: Investigation on the application of steel slag-fly ash-phosphogypsum solidified material as road base material. J. Hazard. Mater. 164, 99-104 (2009)

54. Zielinski, M.: Use of the constant magnetic field-treated industrial waste for stabilization of the road surface subsoil. Przem. Chem. 92, 1453-1460 (2013) (in Polish)

55. Klin, S.: Analysis of the variation of strength and deformability of gypsum in various states of stress and humidity. Zeszyty Nauk. Akad. Rol. Wroclaw 510, rozprawy CCXXCVIII (2005) (in Polish)

56. Isajenko, K., Fujak, M., Piotrowska, B.: Monitoring of ${ }^{137} \mathrm{Cs}$ Concentration in Soil in 2012-2013. Central Laboratory for Radiological Protection, Warszawa (2014) (in Polish)

57. Grabas, K., Hreniak, D., Miller, M., Ostrowski, A., Pawełczyk, A., Stręk, W., Zych, E.: Hydrometallurgical Processing of Mongolian Lanthanide Ore, Rare Earths 2012, Publ. Canadian Inst. of Mining, Metallurgy \& Petroleum, ISBN 9871--926872-14-8, ed. Goode, Moldoveanu, Rayat. Niagara Ont. Canada, pp. 103-110

\section{Affiliations}

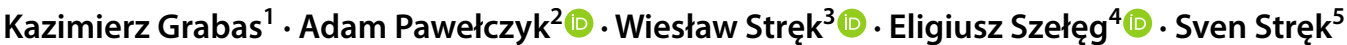

1 "Poltegor Institute" Institute of Opencast Mining, ul. Parkowa 25, 51-616 Wrocław, Poland

2 Faculty of Chemistry, Wroclaw University of Science and Technology, ul. Wyspianskiego 27, 50-370 Wrocław, Poland

3 Institute of Low Temperature and Structural Research, ul. Okólna 2, 50-422 Wrocław, Poland
4 Faculty of Earth Sciences, University of Silesia in Katowice, ul. Bedzinska 60, 41-200 Sosnowiec, Poland

5 IPANTERM, Ltd., ul. Okólna 2, 50-422 Wrocław, Poland 